\title{
Cover crops affecting levels of ammonium and nitrate in the soil and upland rice development
}

\section{Plantas de cobertura afetando os níveis de nitrato e amônio no solo e o desenvolvimento do arroz de terras altas}

\author{
Adriano Stephan Nascente ${ }^{1 *}$; Carlos Alexandre Costa Crusciol ${ }^{2}$
}

\begin{abstract}
The use of cover crops in no-tillage systems (NTS) increases the levels of organic matter and could increase the nitrogen content of the soil, contributing to reduce fertilizers costs. The knowledge of these processes is fundamental for deciding whether cover crops can be effectively incorporated into the agricultural production system. The objective of this study was to evaluate the effect of cover crop species on the levels of nitrate and ammonium in the soil in early upland rice development, as well upland rice yield. A field experiment was performed and treatments consisted of growing rice on five cover crops (Panicum maximum, Brachiaria ruziziensis, Brachiaria brizantha, millet and fallow) in an NTS and two control treatments (Brachiaria brizantha and fallow) under a conventional tillage system, CTS, (one plowing and two disking). The experimental design was a complete randomized block with three replications. The soil samples were collected during a period of six weeks $(0,7,14,21,28$ and 35 days in relation to upland rice sowing). The cover crops Brachiaria brizantha, Panicum maximum and Brachiaria ruziziensis in the NTS and $B$. brizantha fallow incorporated into the CTS favored higher levels of nitrate in the soil. In contrast, B. brizantha and fallow in the CTS and millet and P. maximum in the NTS favored the buildup of high levels of ammonium in the soil. The treatments under the plowed cover crops millet and fallow allowed for a higher upland rice yield. The tillage system and nature of the cover crops could be used to achieve the desired levels and forms of nitrogen in soil.
\end{abstract}

Key words: Brachiaria brizantha, Brachiaria ruziziensis, Panicum maximum, millet, fallow, soil management

\section{Resumo}

O uso de plantas de cobertura no sistema plantio direto (SPD) aumenta os níveis de matéria orgânica e pode ajudar a aumentar os teores de nitrogênio no solo contribuindo para reduzir os custos de fertilizantes. O conhecimento desse processo é fundamental para que as plantas de cobertura possam ser efetivamente incorporadas aos sistemas de produção agrícola. O objetivo deste estudo foi avaliar o efeito de espécies de plantas de cobertura nos níveis de nitrato e amônio no solo durante o desenvolvimento inicial do arroz de terras altas, bem como a produtividade do arroz. Um experimento de campo foi realizado e os tratamentos consistiram de cultivo de arroz sobre cinco plantas de cobertura (Panicum maximum, Brachiaria ruziziensis, Brachiaria brizantha, milheto e pousio) no SPD e mais dois tratamentos controle (Brachiaria brizantha e pousio) no sistema de plantio convencional, PC (uma aração e duas gradagens). O delineamento experimental foi em blocos completos casualizados com três repetições. As amostras de solo foram coletadas por seis semanas $(0,7,14,21,28$ e 35 dias em relação à semeadura do

\footnotetext{
${ }^{1}$ Eng $^{\circ}$ Agr $^{\circ}$, Pesquisador, Dr. Embrapa Arroz e Feijão, Rod. GO-462, km 12 Zona Rural, C P1 179, CEP 75375-000, Santo Antônio de Goiás, GO. E-mail: adriano.nascente@ embrapa.br

${ }^{2}$ Eng $^{\mathrm{o}}$ Agr $^{\mathrm{o}}$, Prof. Titular, Dr. do Dept ${ }^{\mathrm{o}}$ de Produção Vegetal. Universidade Estadual Paulista, UNESP, Faculdade de Ciências Agronômicas, FCA, R. José Barbosa de Barros 1780, C P 237, CEP 18610-307, Botucatu, SP. Bolsista do CNPq. E-mail: crusciol@fca.unesp.br
}

* Author for correspondence 
arroz). As culturas de cobertura B. brizantha, Panicum maximum e B. ruziziensis no SPD e B. brizantha incorporada e pousio incorporado no PC tiveram os níveis mais elevados de nitratos no solo. Por outro lado, $B$. brizantha e pousio no PC e milheto e $P$. máximo no SPD tiveram os níveis mais elevados de amônio no solo. Tratamentos com a planta de cobertura milheto e pousio incorporado proporcionaram as maiores produtividades do arroz. Sistema de cultivo e espécies de plantas de cobertura podem ser usadas para atingir os níveis desejados e a forma de nitrogênio no solo.

Palavras-chave: Brachiaria brizantha, Brachiaria ruziziensis, Panicum maximum, milheto, pousio, manejo do solo

\section{Introduction}

In the last fifteen years, the number of crops cultivated worldwide under a no-tillage system (NTS) has grown impressively. This number was approximately 5 million ha in 1987 (80\% of the area was in the USA) and grew to almost 117 million ha in 2007-08. The higher increase in NTS has taken place in Latin America (58 million ha), the USA and Canada (40 million ha) and Australia (17 million ha) (FAO, 2012).

An important point to be considered is the nature of the cover crop used (DABNEY; DELGADO; REEVES, 2001; FILIZADEH; REZAZADEH; YOUNESSI, 2007; YAHUZA, 2011). The correct identification of cover crop can provide many benefits to the agricultural system (NASCENTE; CRUSCIOL, 2012; NASCENTE; CRUSCIOL; COBUCCI, 2013a). In this regard, the decomposition of cover crops present on the ground may provide a greater availability of nutrients, lower release of possible allelopathic substances to the soil, and, especially, lower levels of nitrogen immobilization by the microbial community in the soil when the nitrogen demand of the crops is high (CRUSCIOL et al., 2012; DIECKOW et al., 2006; LAL, 2004).

It is necessary to study the decomposition of straw in order to provide crops with their nutrient plant demand at the right time. Nitrogen is one of the most dynamic nutrients in the NTS (D'ANDRÉA et al., 2004; SAITO et al., 2005). The buildup of high levels of $\mathrm{N}$ in the soil before crop demand could lead to nitrate loss through leaching or denitrification (MALAVOLTA, 1980). On the other hand, a delay in the release of $\mathrm{N}$ from decomposing crop residues could lead to losses in crop yields (VEIGA;
REINERT; REICHERT, 2010). The amount of nitrogen that will be effectively used by the crop in the succession of cover crops will depend on the timing between the decomposition rate of the cover crop residue and the crop demand (KLIEMANN; BRAZ; SILVEIRA, 2006). Therefore, the cycling of nutrients by cover crops could allow for a better use of soil nutrients, thereby leading to a substantial reduction in the input cost of adding costly fertilizer (ARANDA et al., 2011; BASTIDA et al., 2008; CECCANTI; MASCIANDARO; MACCI, 2007).

The knowledge of these various processes is fundamental for deciding whether cover crops can be effectively incorporated into the agricultural production system (NASCENTE et al., 2011). This knowledge would include knowing the quantities and times of $\mathrm{N}$ release and the availability to meet the crop demand. Moreover, such an understanding will determine the amount of additional fertilizer needed (AITA; PORT; GIACOMINI, 2006). However, in Brazil, information is lacking under field conditions on the dynamics of cover crop decomposition and rate and the form of $\mathrm{N}$ released from cover crop residues (KLIEMANN; BRAZ; SILVEIRA, 2006).

In addition, upland rice is cultivated in Asia, Africa and the Americas mostly by small or subsistence farmers in the poorest regions of the world (AFRICA RICE CENTER, 2005; CGIAR, 2006; OONYU, 2011). However, the reduction of available water resources due to the demands of the industry and population, mainly in Asia, and the search for alternatives to produce rice while allowing a greater economy of water has been in demand (FENG et al., 2007; QU et al., 2008; NASCENTE; CRUSCIOL; COBUCCI, 2013a). 
Some alternatives include growing rice under aerobic conditions, irrigated or not, as well as the use of cover crops to seek a greater soil moisture conservation (BOUMAN et al., 2007; TAO et al., 2006; NASCENTE et al., 2013b). In this regard, the development of technologies that helps to increase the yield of rice on the upland environment, besides producing food and saving more water, could allow for an increase in the revenue of many farmers who depend on this grain to subsist (CGIAR, 2006).

The objective of this study was to evaluate the effect of cover crop species on the levels of nitrate and ammonium in the soil under no-tillage and conventional tillage systems, as well as upland rice yield.

\section{Materials and methods}

\section{Site descriptions}

The field experiment was conducted in Santo Antônio de Goiás, GO (16 $27^{\circ}$ latitude, 49 $17^{\circ}$ ' longitude and $823 \mathrm{~m}$ local elevation). The regional climate is tropical savanna, Aw according to the Koppen classification. There are two well-defined seasons, normally dry from May to September (autumn/winter) and rainy from October to April (spring/summer), usually the growing season. The long-term annual average rainfall is between 1500 $\mathrm{mm}$ and $1700 \mathrm{~mm}$, and the long-term annual average temperature is $22.7^{\circ} \mathrm{C}$, varying annually between $14.2^{\circ} \mathrm{C}$ and $34.8^{\circ} \mathrm{C}$. In addition, climatic data were evaluated during the experiment period (Figure 1).

Figure 1. Rain and temperature at the experimental site during the first six weeks of rice growth. Arrows show sampling times, and the labels are days after sowed rice in each sampling.

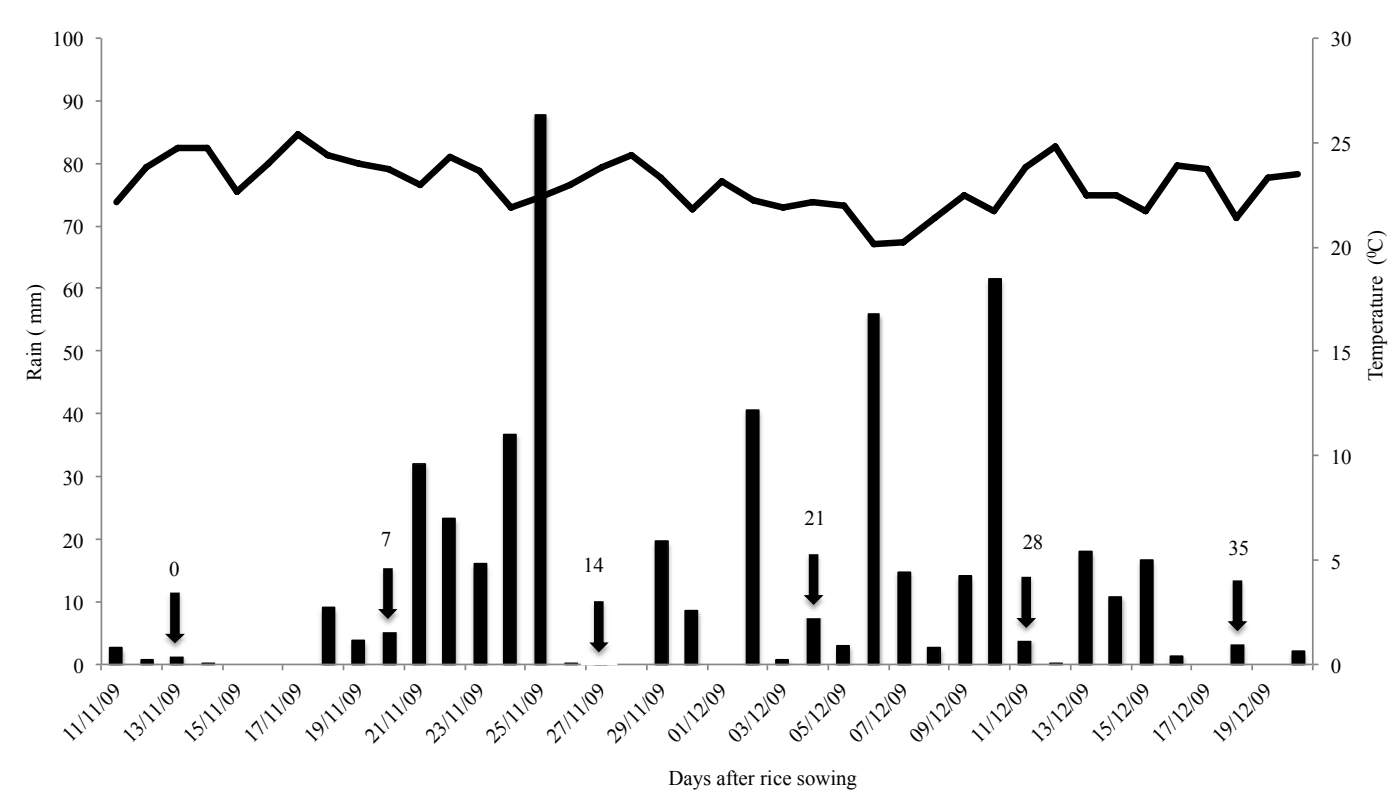

Source: Elaboration of the authors.

The soil was a Rhodic Ferralsol (FAO, 1998) in a gently undulating topography. The soil texture was clayey (540 $\mathrm{g} \mathrm{kg}^{-1}$ clay, $110 \mathrm{~g} \mathrm{~kg}^{-1}$, and $350 \mathrm{~g} \mathrm{~kg}^{-1}$ sand). The research was conducted in an area that had been in NTS for eight years (2001-02 - 2008$09)$ in rotations with corn $(2001-02,2003-04,2005-$
06 and 2007-08), soybean (2002-03, 2004-05 and 2006-07) and upland rice (2008-09) in the summer and fallow in the winter.

Regarding the soil analysis, for the chemical analysis of the soil before the installation of the 
experiment, 48 samples were collected in each of the following layers: $0-0.05 \mathrm{~m}, 0.05-0.10 \mathrm{~m}$ and $0.10-$ $0.20 \mathrm{~m}$ depths (Table 1). $\mathrm{P}$ and $\mathrm{K}$ were extracted by Mehlich 1 extracting solution (0.05 M HC1 in $0.0125 \mathrm{M} \mathrm{H}_{2} \mathrm{SO}_{4}$ ). From the extracted solution, phosphorus was measured colorimetrically and $\mathrm{K}$ by flame photometry. $\mathrm{Ca}, \mathrm{Mg}$, and $\mathrm{Al}$ were extracted with $1 \mathrm{M} \mathrm{KCl}$. Aluminum was collected by titration with $\mathrm{NaOH}$ and $\mathrm{Ca}$ and $\mathrm{Mg}$ by titration with EDTA from the extracted solution. The micronutrients were measured on a portion of the extract for $\mathrm{P}$ by atomic absorption spectrophotometry.

Table 1. Soil chemical properties at the experimental area, 2009.

\begin{tabular}{cccccccccccc}
\hline $\begin{array}{c}\text { Depth } \\
(\mathrm{cm})\end{array}$ & $\mathrm{pH}$ & $\mathrm{Ca}$ & $\mathrm{Mg}$ & $\mathrm{Al}$ & $\mathrm{P}$ & $\mathrm{K}$ & $\mathrm{Cu}$ & $\mathrm{Zn}$ & $\mathrm{Fe}$ & $\mathrm{Mn}$ & $\begin{array}{c}\text { M.O. } \\
\mathrm{g} \mathrm{dm}^{-3}\end{array}$ \\
$0-5$ & 5.7 & 2.8 & 1.4 & 0.0 & 14.6 & 191.9 & 1.5 & 4.9 & 30.6 & 25.2 & 23.0 \\
$5-10$ & 5.7 & 2.1 & 0.8 & 0.0 & 15.4 & 144.9 & 1.8 & 4.4 & 32.2 & 20.9 & 17.5 \\
$10-20$ & 5.5 & 1.8 & 0.5 & 0.1 & 15.9 & 107.7 & 1.9 & 4.0 & 32.3 & 18.4 & 13.5 \\
\hline
\end{tabular}

Source: Elaboration of the authors.

\section{Experimental design and treatments}

The experimental design was randomized blocks with five cover crops + two control treatments with three replications, totaling 21 plots. Each plot measured $6.0 \mathrm{~m} \times 10 \mathrm{~m}$. The cover crops used to grow rice in the no-tillage system were as follows: 1 - fallow (spontaneous vegetation, predominantly Bidens pilosa, Commelina benghalensis, Conyza bonariensis and Cenchrus echinatus); 2 - Panicum maximum; 3 - Brachiaria ruziziensis; 4 - Brachiaria brizantha; and 5 - millet (Pennisetum glaucum). Beside these treatments, two additional treatments considered controls were included in growing rice in the conventional tillage system (CTS), 1 plowing and 2 disking: $6-B$. brizantha and 7 - fallow (spontaneous vegetation) incorporated 30 days before rice sowing.

\section{Crop management}

The cover crops were sowed in the off-season (March 2009). For this sowing, tropical forages were planted in $0.20 \mathrm{~m}$ rows using a mechanical planter set to distribute $10 \mathrm{~kg}$ seeds $\mathrm{ha}^{-1}$ with at least $30 \%$ viable seed germination without fertilization. In the following summer (November 2009), the cultivar of upland rice (Oryza sativa L.) BRS Sertaneja was sowed, spaced $0.35 \mathrm{~m}$ apart with a population of 60 plants per meter, using the fertilization of $20 \mathrm{~kg} \mathrm{ha}^{-1}$ $\mathrm{N}$ as urea, $120 \mathrm{~kg} \mathrm{ha}^{-1} \mathrm{P}_{2} \mathrm{O}_{5}$ as triple super phosphate and $60 \mathrm{~kg} \mathrm{ha}^{-1} \mathrm{~K}_{2} \mathrm{O}$ as potassium chloride and, for

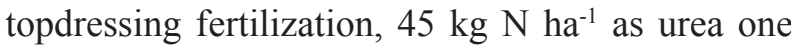
day after the upland rice was seeded and later, at the beginning of the tillering stage, $45 \mathrm{~kg} \mathrm{~N} \mathrm{ha}^{-1}$ as urea. Culture management was performed according to rice needs.

Herbicide was applied to all cover crops of the NTS treatments 30 days before and on the upland rice sowing day right before the sowing operation. The herbicide glyphosate was used at a $1.8 \mathrm{~kg} \mathrm{ha}^{-1}$ acid equivalent. For this application, a boom sprayer was used with a spray volume of 200 liters $\mathrm{ha}^{-1}$. The environmental conditions during pulverization were weak winds, a temperature of approximately $25^{\circ} \mathrm{C}$ and relative humidity around $80 \%$. This operation was performed after drying the dew on the cover crop leaves.

\section{Soil sampling}

The soil sampling was performed with an auger on the upland rice sowing day (30 days after 
cover crop desiccation) and five additional times (7, 14, 21, 28 and 35 days) in all treatments and replications following the method suggested by Aita, Port and Giacomini (2006), Pacheco (2009), and Oliveira (2010). Thus, eight sub-samples were collected in each composite sample from each plot at a depth $0-10 \mathrm{~cm}$, which were homogenized by hand, labeled, wrapped in plastic bags, kept in a cooler with ice and sent to the lab for analysis.

\section{$\mathrm{N}-\mathrm{NH}_{4}^{+}$and $\mathrm{N}-\mathrm{NO}_{3}^{-}$evaluation}

The analyses of mineral $\mathrm{N}$ were performed the same day of soil sample collection. From each soil sample, a representative aliquot of $20 \mathrm{~g}$ was removed and mixed with $60 \mathrm{ml}$ of extraction solution $\mathrm{KCl} 2 \mathrm{~mol} \mathrm{~L}^{-1}$. (BREMNER, 1965). After shaking for an hour and decanting the solid material, the supernatant was filtered using filter paper. This supernatant was used to quantify the levels of nitrate and ammonium.

For this experiment, the method proposed by Griess (1879) was used in which nitrate was quantified indirectly in the form of the nitrite ion after the reaction with sulphanilamide and $\mathrm{N}-\alpha$ naphthalene diamine. The ammonium was measured according to the methodology of Berthelot (1859). Both mineral nitrogen sources were measured by spectrophotometry coupled to an FIA ("Flow Injection Analysis") following the methodology used by Gine et al. (1980).

Parallel to the determination of mineral N, the moisture from the soil samples was determined by weighing immediately after soil sampling and then drying in an oven at $105^{\circ} \mathrm{C}$ for $72 \mathrm{~h}$, weighing again to calculate the dry weight, and aiming at presenting the results of ammonium and nitrate on a dry basis. The amounts of $\mathrm{N}^{-\mathrm{NH}_{4}}{ }^{+}$and $\mathrm{N}-\mathrm{NO}_{3}{ }^{-}$were expressed in $\mathrm{mg} \mathrm{kg}^{-1}$ dry soil, considering the concentration of these forms of $\mathrm{N}$ in the layer evaluated. The soil $\mathrm{pH}$ in water was already measured using a $\mathrm{pH}$ meter during the $\mathrm{N}-\mathrm{NH}_{4}{ }^{+}$and $\mathrm{N}-\mathrm{NO}_{3}{ }^{-}$evaluations.

\section{Dry matter cover crop degradation}

At the beginning of rice development (30 days after cover crop desiccation) and every 7 days (same day sampling of ammonium and nitrate in the soil) a total of seven assessments $(0,7,14,21$, 28 and 35 days after rice sowing) were collected, and the dry matter of the cover crops was evaluated. The samples were taken using a hollow metallic square of $1.0 \mathrm{~m} \mathrm{x} 1.0 \mathrm{~m}\left(1.0 \mathrm{~m}^{2}\right)$ thrown at random in each plot. All plant material was collected using the methodology proposed by Crusciol and Soratto (2009) and Nascente, Pereira and Medeiros (2004). The plant samples were placed in paper bags and dried in an oven with forced ventilation at $65^{\circ} \mathrm{C}$ until constant weight of plant dry matter.

To evaluate cover crop degradation, an exponential mathematical model was used (OLIVEIRA, 2010; PACHECO, 2009; THOMAS; ASAKAWA, 1993) with the formula

$$
\mathrm{y}=\mathrm{y}_{0} \cdot \mathrm{e}^{(-\mathrm{kt})} \text {, equation (1), }
$$

where $y$ is the fraction of initial residue existing at time $t, y_{0}$ is the proportion of potentially decomposable residue and $\mathrm{k}$ is the constant of decomposition of the residue. With the data, a graphic of the dry matter degradation of each species of plant cover was made.

\section{Upland rice yield}

The manual harvest of upland rice was conducted when approximately $90 \%$ of panicles had grains of typical mature coloration. Therefore, the grain yield was measured (unhulled grain weight collected at three central rows of five meters in each split-plot, eliminating 2.5 meters on each side of the plots from the usable areas, correcting their moisture content to $130 \mathrm{~g} \mathrm{~kg}^{-1}$ and converting to $\mathrm{kg} \mathrm{ha}^{-1}$ ).

\section{Statistical analysis}

All data were analyzed using the Statistical Software Package SAS (SAS INSTITUTE, 1999). 
The cropping system (five cover crops + two control, totaling seven treatments) and sampling day $(0,7,14,21,28$ and 35 days after upland rice sowing) were considered fixed effects. Two error terms were considered in the analysis of the data, one associated with the cropping system and the other associated with the sampling day and the interaction (cropping system x sampling day). Mean separations were conducted using the LSD test. The effects were considered statistically significant at $\mathrm{P} \leq 0.05$, as by Aita, Port and Giacomini (2006), Nascente, Crusciol and Cobucci (2013a) and Nascente et al. (2013b). If necessary, a polynomial regression analysis was also performed for cover crop degradation and mineral $\mathrm{N}$ data for each type of straw depending on the sampling day.

\section{Results and Discussions}

\section{Nitrate}

Regarding nitrate, there were effects of the cover crops, sampling day and interaction (Table 2). The application of urea 1 day after upland rice sowing favored increased levels of nitrate in the soil in all plots, which was observed in the subsequent sampling (7 days) (Figure 2).

Table 2. Variance analyses of nitrate, ammonium, the nitrate ammonium rate, $\mathrm{pH}$ and rice yield under soil cultivated with cover crops.

\begin{tabular}{lccccc}
\hline Variable & Nitrate & Ammonium & $\mathrm{NO}_{3}^{-} / \mathrm{NH}_{4}^{+}$ & $\mathrm{pH}$ & Rice Yield \\
\hline Cover crop (C) & $<0.001$ & 0.5467 & 0.8786 & $<0.001$ & $<0.001$ \\
Sampling day (D) & $<0.001$ & $<0.001$ & $<0.001$ & $<0.001$ & - \\
$\mathrm{C} * \mathrm{D}$ & 0.0423 & 0.8793 & 0.7584 & $<0.001$ & - \\
\hline
\end{tabular}

Source: Elaboration of the authors.

Additionally, Oliveira (2010) and Pacheco (2009) found increased levels of nitrate in the soil after the application of nitrogen fertilizers; this result can be explained by the input of nitrogen to the soil (FAGERIA; MOREIRA; COELHO, 2011). In this sense, after urea application, an increase of ammonium in the soil was expected. However, in the soil, urea is hydrolyzed by the action of urease in two or three days, producing ammonium carbonate, and then $\mathrm{NH}_{3}, \mathrm{CO}_{2}$ and water (FAGERIA, 2009). Ammonia $\left(\mathrm{NH}_{3}\right)$, depending on the $\mathrm{pH}$ and soil moisture, can be lost by evaporation. However, part of this molecule is converted to $\mathrm{NH}_{4}^{+}$. In this aerobic environment, the metabolism from ammonium to nitrate through the intermediate form nitrite, in a process called nitrification, is rapid (FAGERIA; MOREIRA; COELHO, 2011). Therefore, as the second sampling was performed six days after urea application, it was possibly too late to measure ammonium before it changed to nitrate (MALAVOLTA, 1980). 
Figure 2. Nitrate, ammonium and nitrate/ammonium in the soil under cover crops in tillage and no-tillage systems in the first six weeks of rice growing.
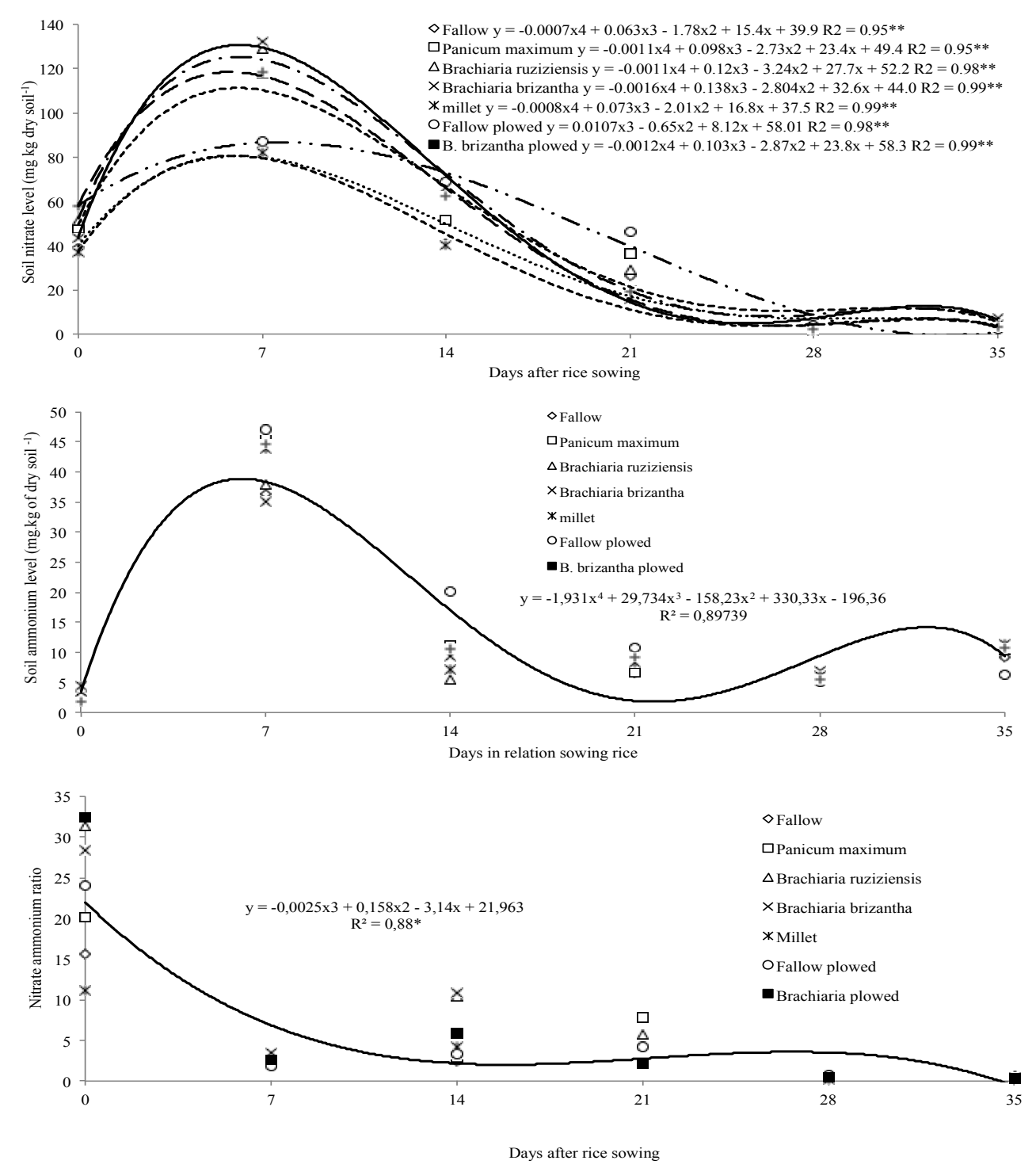

Source: Elaboration of the authors.

The soil level of nitrate was different among the cover crops used (Table 3). The amount of nitrate was lower in the cover crops millet and fallow, and these crops were different from all other cover crops, mainly in the first three weeks of rice development (Figure 3). A sharp drop in the soil nitrate levels was also observed for all cover crops after the third sampling (14 days). This drop occurred partly because of the root development of the upland rice plants, as they absorb nitrogen from the soil as they grow (FAGERIA, 2009; MALAVOLTA, 1980).
However, this result also reflects the large amount of rainfall that had occurred in the experimental area (Figure 1). One day before the fourth soil sampling, there was $40.6 \mathrm{~mm}$ of rain, and between the fifth and sixth samplings, $160 \mathrm{~mm}$ of rainfall water accumulated, $61.40 \mathrm{~mm}$ of which fell down in the night prior to this fifth soil sampling. According to D'Andréa et al. (2004), nitrate is easily leachable and this leaching is directly related to the volume of water precipitated. This relationship is because there is a predominance of negative charges in the 
soil and $\mathrm{NO}_{3}^{-}$has a low chemical interaction with the soil minerals, therefore causing the easy loss of this anion following the downward flow of water that percolates through the soil profile (FAGERIA, 2009).

At an average of six weeks, the nitrate levels were higher in plots with $P$. maximum $(44.02 \mathrm{mg}$ $\mathrm{kg}$ dry soil ${ }^{-1}$ ), B. ruziziensis $\left(42.26 \mathrm{mg} \mathrm{kg}\right.$ dry soil ${ }^{-}$ $\left.{ }^{1}\right)$ and $B$. brizantha (45.59 $\mathrm{mg} \mathrm{kg}$ dry soil $\left.{ }^{-1}\right)$ in the NTS and $B$. brizantha plowed (44.03 $\mathrm{mg} \mathrm{kg}$ dry soil $^{-1}$ ) and fallow plowed (44.47 mg kg dry soil ${ }^{-}$ $\left.{ }^{1}\right)$ in the conventional tillage system (Table 3 ). In the conventional tillage system, it is usual to find a larger amount of nitrate, which may be related to the increased mineralization of organic matter in this type of soil management after plowing (FAGERIA, 2009; VEIGA; REINERT; REICHERT, 2010).

Table 3. Levels of nitrate and ammonium (average of the first 6 weeks of upland rice development) at depths from 0 to $10 \mathrm{~cm}$ and rice yield under soil with rice cover crops in tillage and no-tillage systems.

\begin{tabular}{|c|c|c|c|}
\hline Treatments & Nitrate & Ammonium & Rice yield \\
\hline & \multicolumn{2}{|c|}{----------mg kg dry soil'-1----------- } & $\mathrm{kg} \mathrm{ha}^{-1}$ \\
\hline Fallow & $32.98 \mathrm{~b}$ & $12.00 \mathrm{~b}$ & $3,460 \mathrm{~b}$ \\
\hline Panicum maximum & $44.02 \mathrm{a}$ & $14.10 \mathrm{a}$ & $2,857 \mathrm{~cd}$ \\
\hline Brachiaria ruziziensis & $42.26 \mathrm{a}$ & $11.90 \mathrm{~b}$ & $2,177 \mathrm{~d}$ \\
\hline Brachiaria brizantha & $45.59 \mathrm{a}$ & $12.26 \mathrm{~b}$ & $2,356 \mathrm{~d}$ \\
\hline Millet & $30.24 \mathrm{~b}$ & $13.57 \mathrm{a}$ & $4,263 \mathrm{a}$ \\
\hline Fallow plowed & $44.47 \mathrm{a}$ & $15.32 \mathrm{a}$ & $3,774 \mathrm{ab}$ \\
\hline Brachiaria brizantha plowed & $44.03 \mathrm{a}$ & $13.74 \mathrm{a}$ & $2,616 \mathrm{~cd}$ \\
\hline Average & 40.40 & 12.91 & 2,287 \\
\hline
\end{tabular}

* Same lower case letters vertically do not differ by the LSD test at $\mathrm{p}<0.05$.

Source: Elaboration of the authors.

Figure 3. Cover crop dry matter degradation after rice sowing and regression analysis. ${ }^{* *}$ Significant by the $\mathrm{F}$ test at $\mathrm{p}<0.01$.

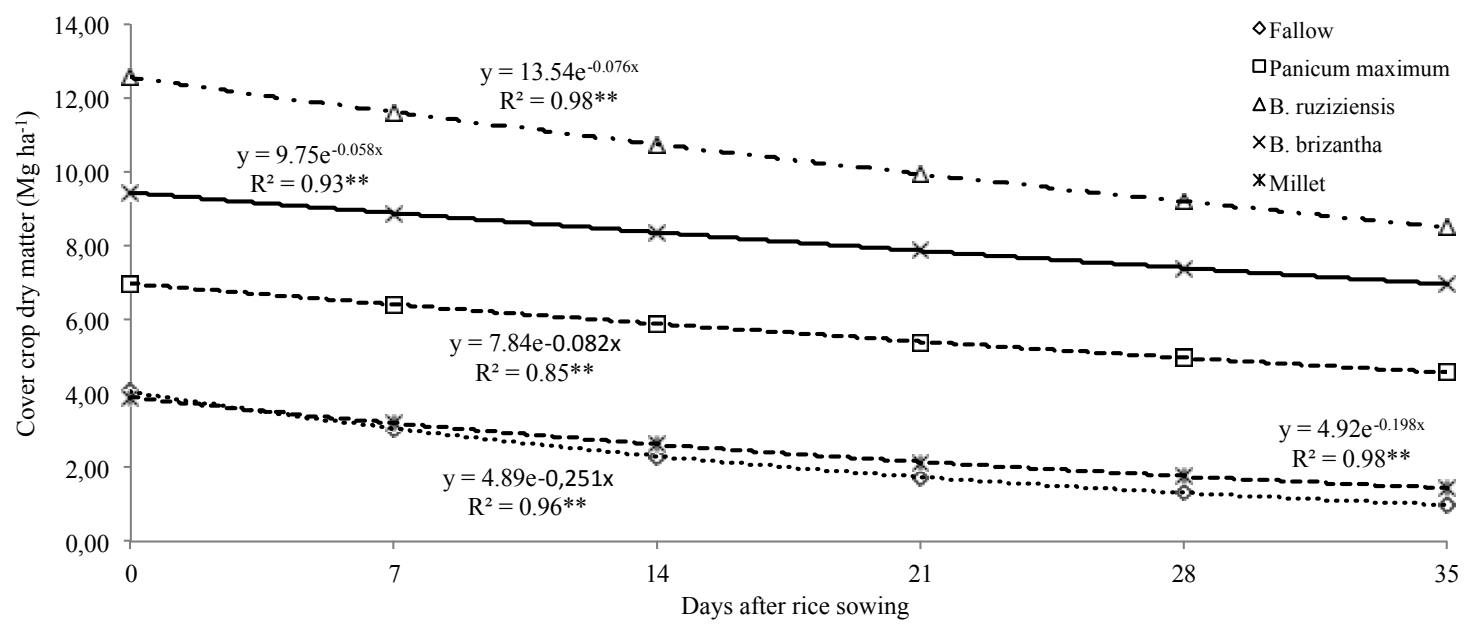

Source: Elaboration of the authors. 


\section{Cover crop degradation}

Regarding the cover crops in NTS, the results corroborate with those obtained by Boer et al. (2007), D’Andréa et al. (2004), Pacheco (2009) and Rosolem, Werle and Garcia (2010), who found a large amount of nitrate in the NTS. According to these authors, during straw degradation, ammonium is produced first, but due to the humidity, temperature stability, $\mathrm{pH}$ and the presence of oxygen, the activity of bacteria that transform ammonium to nitrate faster than in conventional tillage is favored. Beside this favoritism, large amounts of cover crop dry matter are produced in NTS (Figure 3) and, after herbicide application in those plants, most likely due to high temperatures and humidity, straw degradation is favored, increasing the levels of nitrogen in the soil. According to Boer et al. (2007) and Rosolem, Werle and Garcia (2010), the high N mineralization rate is also correlated to the rapid plant residue decomposition (Figure 2). Similar results were obtained by Oliveira (2010), where B. brizantha straw favored increased levels of nitrogen in the soil in NTS. These results demonstrate that the use of cover crops with large biomass production could lead to an increase in the nitrogen content of the soil that can be used by the crops that follow.

As for millet and fallow, the straw values of nitrate were lower than the other treatments, differing by the "LSD" test (Table 3). This difference seems again to be related to the amount of dry matter produced by the covers. Millet and fallow produced the lowest amount of biomass and also favored the lowest levels of these ions in the soil (Table 3 and Figure 3).

\section{Ammonium}

It was also found that the levels of ammonium after nitrogen fertilization (1 day after upland rice sowing) increased in the soil (Figure 2). A regression analysis showed no interaction between the cover crops and sampling time (Table 2). On average, fallow (12.00 mg kg dry soil $\left.{ }^{-1}\right)$, B. ruziziensis $(11.90$ mg kg dry soil $\left.{ }^{-1}\right)$ and $B$. brizantha (12.26 mg kg dry soil ${ }^{-1}$ ) in NTS were significantly different from millet (13.57 $\mathrm{mg} \mathrm{kg}$ dry soil $^{-1}$ ) in NTS and fallow plowed (15.32 mg kg dry soil ${ }^{-1}$ ) (Table 3$)$. It was also observed that the crop covers $B$. brizantha and fallow in the conventional tillage system and millet and $P$. maximum in the NTS had, on average, the largest ammonium values and did not differ from each other by the LSD test but differed from the other cover crops. These results can be explained by the conventional tillage system favoring organic matter mineralization and by ammonium being the first nitrogen compound generated (FAGERIA, 2009). Beside this result, Panicum maximum and millet showed a rapid degradation and also the fastest delivery of this ion to the soil (Figure 2).

Additionally, the amount of nitrate was much larger than that of ammonium (Table 3). This result is typical of well-drained soils, such as the Brazilian Cerrado (FAGERIA, 2009). Normally, the average concentrations of $\mathrm{NH}_{4}^{+}$found in agricultural soils are smaller than those of $\mathrm{NO}_{3}^{-}$(MARSCHNER, 1995; OWEN; JONES, 2001; POLETTO; GROHS; MUNDSTOCK, 2008), which occurs mainly due to limitations in ammonium diffusion (SCHJOERRING et al., 2002) and to the rapid oxidation from $\mathrm{NH}_{4}^{+}$to $\mathrm{NO}_{3}^{-}$by nitrifying bacteria (NORTON, 2000).

\section{$p H$}

After nitrogen fertilization with urea (day 1), there was a reduction in the soil $\mathrm{pH}$ in all of the plots, which was observed in two subsequent samples at 7 and 14 days after rice sowing in all treatments, compared with day 0 (Table 4 ). This increased acidity is possibly caused by the use of nitrogen fertilizer (urea) when it releases hydrogen ions that contribute to soil acidification (FAGERIA, 2009), as observed in this trial. It was also found that from the fourth sampling, the $\mathrm{pH}$ values increased in the soil of all plots. This increase is possibly due to the plants releasing $\mathrm{OH}^{-}$ bound to $\mathrm{H}^{+}$and raising the $\mathrm{pH}$ to maintain the internal equilibrium when they absorb nitrate (MALAVOLTA, 1980; MARSCHNER, 1995). 
Table 4. Values of $\mathrm{pH}$ during the first six weeks of rice plant development under cover crops in the no-tillage and conventional tillage systems.

\begin{tabular}{lcccccl}
\hline \multicolumn{1}{c}{ Treatments } & \multicolumn{7}{c}{ Days after rice sowing } \\
\hline & 0 & 7 & 14 & 21 & 28 & 35 \\
Fallow & $5.94 \mathrm{a} \mathrm{B}$ & $5.83 \mathrm{abc} \mathrm{C}$ & $5.48 \mathrm{ab} \mathrm{D}$ & $5.75 \mathrm{~b} \mathrm{C}$ & $5.94 \mathrm{bc} \mathrm{B}$ & $6.12 \mathrm{ab} \mathrm{A}$ \\
P. maximum & $5.88 \mathrm{ab} \mathrm{B}$ & $5.78 \mathrm{abc} \mathrm{B}$ & $5.34 \mathrm{~b} \mathrm{D}$ & $5.61 \mathrm{c} \mathrm{C}$ & $5.87 \mathrm{c} \mathrm{B}$ & $6.04 \mathrm{bcd} \mathrm{A}$ \\
B. ruziziensis & $5.74 \mathrm{bc} \mathrm{B}$ & $5.92 \mathrm{ab} \mathrm{A}$ & $5.44 \mathrm{ab} \mathrm{C}$ & $5.56 \mathrm{c} \mathrm{C}$ & $5.88 \mathrm{c} \mathrm{A}$ & $5.97 \mathrm{~cd} \mathrm{~A}$ \\
B. brizantha & $5.96 \mathrm{a} \mathrm{A}$ & $5.83 \mathrm{abc} \mathrm{A}$ & $5.37 \mathrm{~b} \mathrm{~B}$ & $5.50 \mathrm{c} \mathrm{B}$ & $5.84 \mathrm{c} \mathrm{A}$ & $5.94 \mathrm{~d} \mathrm{~A}$ \\
Millet & $6.02 \mathrm{a} \mathrm{AB}$ & $5.93 \mathrm{a} \mathrm{B}$ & $5.42 \mathrm{~b} \mathrm{C}$ & $5.93 \mathrm{a} \mathrm{B}$ & $6.05 \mathrm{ab} \mathrm{AB}$ & $6.17 \mathrm{ab} \mathrm{A}$ \\
Fallow plowed & $5.70 \mathrm{c} \mathrm{B}$ & $5.70 \mathrm{c} \mathrm{B}$ & $5.30 \mathrm{~b} \mathrm{C}$ & $5.57 \mathrm{c} \mathrm{B}$ & $6.13 \mathrm{a} \mathrm{A}$ & $6.15 \mathrm{bc} \mathrm{A}$ \\
B. brizantha plowed & $5.97 \mathrm{a} \mathrm{BC}$ & $5.73 \mathrm{bc} \mathrm{CD}$ & $5.67 \mathrm{a} \mathrm{D}$ & $5.87 \mathrm{ab} \mathrm{BC}$ & $6.07 \mathrm{ab} \mathrm{AB}$ & $6.27 \mathrm{a} \mathrm{A}$ \\
\hline
\end{tabular}

*Same upper case letter horizontally or lower case letter vertically do not differ at $\mathrm{p}<0.05$ by the LSD test.

Source: Elaboration of the authors.

\section{Upland rice yield}

It could be seen that millet in the no-tillage system allowed for the statistically highest upland rice yield and was similar to fallow plowed and differed from all other treatments (Table 3). This result may have occurred because upland rice crop seems to "prefer" ammonium nitrogen or the lowest nitrate ammonium rate in the first weeks of its development (MALAVOLTA, 1980). Millet, in this regard, for almost all six samplings, stood out as having the lowest values of nitrate (Table 3 and Figure 2). These data are extremely important because again, upland rice plants are different from most agricultural crops because it comes from a hydrophilic environment (MALAVOLTA, 1980; FAGERIA; MOREIRA; COELHO, 2011), which prevails ammonium (HOLZSCHUH et al., 2009; SCHJOERRING et al., 2002; WANG et al., 1993). Therefore, upland rice has difficulty in synthesizing nitrate in its first month of development due to a lack of the nitrate reductase enzyme. This fact may explain the low initial rice development when only $\mathrm{N}_{-} \mathrm{NO}_{3}^{-}$prevails in the environment with a reflex in rice yield (HOLZSCHUH et al., 2009; MALAVOLTA, 1980), as observed under $B$. brizantha, B. ruziziensis and Panicum maximum.

Kronzucker et al. (1998) and Wang et al. (1993) showed that upland rice plants develop better when higher levels of $\mathrm{N}^{-\mathrm{NH}_{4}}{ }^{+}$are available in its early development. However, Holzschuh et al. (2009) warn that only ammonium in the environment can be prejudicial for rice plants. Therefore, cover crops that can provide larger amounts of $\mathrm{N}_{-} \mathrm{NH}_{4}^{+}$or a lower nitrate ammonium rate in the early development of upland rice may provide a good strategy to allow this crop in NTS. Millet, in this regard, seems to be the best option (Figure 2), allowing the highest upland rice yield in this trial (Table 3).

In this regard, upland rice is grown worldwide on irrigated land (QU et al., 2008). However, the reduction of available water resources due to the demands of industry and the population requires the search for alternatives that allow a greater economy of water (FENG et al., 2007; QU et al., 2008). Some alternatives include growing rice under aerobic conditions, irrigated or not, and also the use of cover crops, seeking a greater conservation of soil moisture (BOUMAN et al., 2007; TAO et al., 2006). Upland rice is cultivated in Asia, Africa and the Americas mostly by small or subsistence farmers in the poorest regions of the world (AFRICA RICE CENTER, 2005; OONYU, 2011). Therefore, development of technologies that help to increase the yield of rice on upland environments, besides producing food and saving more water, could allow for an increase in the revenue of many farmers who depend of this grain to subsist (CGIAR, 2006). 
In this study, it could be observed that plowed millet and fallow had the statistically highest upland rice yields. However, plowed fallow that causes soil disturbances and is therefore not eligible for the notillage system does not seem to be a good option. On the other hand, the worst rice yields were found under cover crops Brachiaria brizantha, Panicum maximum and Brachiaria ruziziensis in the NTS (2356, 2857 and $2177 \mathrm{~kg} \mathrm{ha}^{-1}$, respectively). Moreover, those grasses may have some allelopathic effect that hampers aerobic rice plant development. Martins, Martins and Costa (2006), Souza Filho, Rodrigues and Rodrigues (1997), and Souza et al. (2006) reported allelopathic effects caused by species of Brachiaria in rice. Therefore, from the data obtained, Brachiaria brizantha, B. ruziziensis and Panicum maximum, despite their importance in NTS for producing large amounts of biomass (Figure 3), do not seem to be the ideal cover crop for upland rice. However, in an agricultural system, we could infer that before upland rice, it is important to introduce millet. After upland rice harvesting, perennial forage, such as Panicum maximum, Brachiaria brizantha or B. ruziziensis, could be introduced to achieve a great amount of cover crop in the beginning of the following rainy season and to cultivate another cash crop. Allen et al. (2005) observed a higher cotton yield under forage species than cotton monoculture. Kluthcouski et al. (2000) obtained higher corn, soybean and common bean yields using straws of Panicum maximum and $B$. brizantha. Crusciol et al. (2010) also had better results with a soybean crop on Brachiaria straw. Nascente and Crusciol (2012) had the highest soybean yield under Brachiaria brizantha, $B$. ruziziensis, Panicum maximum and millet under NTS that differed from plowed fallow.

\section{Conclusions}

The cover crops Brachiaria brizantha, Panicum maximum and Brachiaria ruziziensis in the NTS and $B$. brizantha and fallow incorporated in the
CTS favored higher levels of nitrate in the soil. On the other hand, B. brizantha and fallow in the CTS and millet and $P$. maximum in the NTS favored the buildup of high levels of ammonium in the soil. The treatments under the plowed cover crops millet and fallow allowed for the statistically highest upland rice yield. The tillage system and the nature of cover crops could be used to achieve the desired levels and forms of nitrogen in the soil.

\section{Acknowledgments}

We thank Empresa Brasileira de Pesquisa Agropecuária - Embrapa for financial support and a doctorate scholarship to the first author and the Conselho Nacional de Desenvolvimento Científico e Tecnológico - CNPq for a productivity scholarship to the second author.

\section{References}

AFRICA RICE CENTER -WARDA. Annual report 2003-2004. Cotonou, 2005. 56 p.

AITA, C.; PORT, O.; GIACOMINI, S. J. Dynamics of soil nitrogen and cover crops dry matter production in the fall/winter as affected by pig slurry use. Revista Brasileira Ciência do Solo, Viçosa, v. 30, n. 5, p. 901910, 2006.

ALlEN, V. G.; BROWN, C. P.; KELLISON, R.; SEGARRA, E.; WHEELER, T.; DOTRAY, P. A.; CONKWRIGHT, J. C.; GREEN, C. J.; ACOSTAMARTINEZ, V. Integrating cotton and beef production to reduce water withdrawal from the Ogallala aquifer in the southern High Plains. Agronomy Journal, Madison, v. 97, n. 2, p. 556-567, 2005.

ARANDA, V.; AYORA-CAÑADA, M. J.; DOMINGUEZ-VIDAL, A.; MARTÍN-GARCÍA, J. M.; CALERO, J.; DELGADO, R.; VERDEJO, T.; GONZÁLEZ-VILA, F. J. Effect of soil type and management (organic vs. conventional) on soil organic matter quality in olive groves in a semi-arid environment in Sierra Mágina Natural Park (S Spain). Geoderma, Amsterdam, v. 164, n. 1-2, p. 54-63, 2011.

BASTIDA, F.; ZSOLNAY, A.; HERNANDEZ, T.; GARCIA, C. Past, present and future of soil quality indices: a biological perspective. Geoderma, Amsterdam, v. 147, n. 3-4, p. 159-171, 2008. 
BERTHELOT, M. P. E. Violet d'aniline. Repertoire Chimique Application, Paris, v. 1, p. 282-284, 1859.

BOER, C. A.; ASSIS, R. L.; SILVA, G. P.; BRAZ, A. J. B. P.; BARROSO, A. L. L.; CARGNELUTTI FILHO, A.; PIRES, F. R. Nutrient cycling in off-season cover crops on a Brazilian savanna soil. Pesquisa Agropecuária Brasileira, Brasília, v. 42, n. 9, p. 1269-1276, 2007.

BOUMAN, B. A. M.; FENG, L. P.; TUONG, T. P.; LU, G. A.; WANG, H. Q. Exploring options to grow rice using less water in northern China using a modeling approach II: Quantifying yield, water balance components, and water productivity. Agricultural Water Management, Amsterdam, v. 88, n. 1-3, p. 23-33, 2007.

BREMNER, J. M. Total nitrogen. In: BLACK, C. A. (Ed.). Methods of soil analysis: chemical and microbiological properties. Madison: American Society of Agronomy, 1965. p. 1149-1178. (Agronomy, 9).

CECCANTI, B.; MASCIANDARO, G.; MACCI, C. Pyrolysis-gas chromatography to evaluate the organic matter quality of a mulched soil. Soil \& Tillage Research, Amsterdam, v. 97, n. 1, p. 71-78, 2007.

CGIAR. Science council. IRRI's upland rice research: follow-up review to the $6^{\text {th }}$ IRRI external program management review. Rome, 2006. 56 p.

CRUSCIOL, C. A. C.; MATEUS, G. P.; NASCENTE, A. S.; MARTINS, P. O.; BORGHI, E.; PARIZ, C. M. An innovative crop-forage intercrop system: early cycle soybean cultivars and palisadegrass. Agronomy Journal, Madison, v. 104, n. 4, p. 1085-1095, 2012.

CRUSCIOL, C. A. C.; SORATTO, R. P. Nitrogen supply for cover crops and effects on peanut grown in succession under a no-till system. Agronomy Journal, Madison, v. 101, n. 1, p. 41-46, 2009.

CRUSCIOL, C. A. C.; SORATTO, R. P.; BORGHI, E.; MATHEUS, G. P. Benefits of integrating crops and tropical pastures as systems of production. Better Crops International, Atlanta, v. 94, n. 2, p. 14-16, 2010.

D'ANDRÉA, A. F.; SILVA, M. L. N.; CURI, N.; GUILHERME, L. R. G. Carbon and nitrogen storage, and inorganic nitrogen forms in a soil under different management systems. Pesquisa Agropecuária Brasileira, Brasília, v. 39, n. 2, p. 179-186, 2004.

DABNEY, S. M.; DELGADO, J. A.; REEVES, D. W. Use of winter cover crops to improve soil and water quality. Communications in Soil Science and Plant Analysis, New York, v. 7, n. 7-8, p. 1221-1250, 2001.
DIECKOW, J.; MIELNICZUK, J.; GONZÁLEZ-VILA, F. J.; KNICKER, H.; BAYER, C. No-till cropping systems and $\mathrm{N}$ fertilization influences on organic matter composition of physical fractions of a subtropical Acrisol as assessed by analytical pyrolysis (Py- GC/MS). Geoderma, Amsterdam, v. 135, p. 260-268, 2006.

FAGERIA, N. K. The use of nutrients in crops plants. Boca Raton: CRC Press, 2009. 430 p.

FAGERIA, N. K.; MOREIRA, A.; COELHO, A. M. Yield and yield components of upland rice as influenced by nitrogen sources. Journal of Plant Nutrition, London, v. 34, n. 3, p. 361-370, 2011.

FOOD AND AGRICULTURE ORGANIZATION OF THE UNITED NATIONS - FAO. World reference base for soil resources. Rome, 1998. Available at: <http:// www.fao.org/docrep/W 8594E/W 8594E00.htm>. Acessed at: 13 mar. 2012.

Conservation agriculture adoptions worldwide. 2012. Available at: <http://www.fao.org/ag/ca/6c.html>. Acessed at: 10 may 2012.

FENG, L. P.; BOUMAN, B. A. M.; TUONG, T. P.; CABANGON, R. J.; LI, Y. L.; LU, G. A.; FENG, Y. $\mathrm{H}$. Exploring options to grow rice under water-short conditions in northern China using a modeling approach. I: field experiments and model evaluation. Agricultural Water Management, Amsterdam, v. 88, n. 1-3, p. 1-13, 2007.

FILIZADEH, Y.; REZAZADEH, A.; YOUNESSI, $Z$. Effects of crop rotation and tillage depth on weed competition and yield of rice in the paddy fields of Northern Iran. Journal of Agriculture Science and Technology, Teheran, v. 9, n. 2, p. 99-105, 2007.

GINE, M. F.; BERGAMIN FILHO, H.; ZAGATO, E. A. G.; REIS, B. F. Simultaneous determination of nitrate and nitrite by flow injection analysis. Analytica Chimica Acta, Amsterdam, v. 114, p. 191-197, 1980.

GRIESS, P. Bemerkungen zu der abhandlung der H. H. Weselsky und Benedikt .Ueber einige azoverbindungen. Chemische Berrichte, Weinheim, v. 12, p. 426-428, 1879.

HOLZSCHUH, M. J.; BOHNEN, H.; ANGHINONI, I.; MEURER, E. J.; CARMONA, F. C.; COSTA, S. E. V. G. A. Rice growth as affected by combined ammonium and nitrate supply. Revista Brasileira de Ciência do Solo, Viçosa, v. 33, n. 5, p. 1323-1331, 2009.

KLIEMANN, H. J.; BRAZ, A. J. P. B.; SILVEIRA, P. M. Decomposition rate of cover crop residues on a dystrophic oxisol. Pesquisa Agropecuária Tropical, Goiânia, v. 36, n. 1, p. 21-28, 2006. 
KLUTHCOUSKI, J.; FANCELLI, A. L.; DOURADONETO, D.; RIBEIRO, C. M.; FERRARO, L. A. Yield of soybean, corn, common bean and rice under no-tillage management. Scientia Agricola, Piracicaba, v. 57, n. 1, p. 97-104, 2000.

KRONZUCKER, H. J.; KIRK, G. J. D.; SIDDIQI, M. Y.; GLASS, A. D. M. Effects of hypoxia on ${ }^{13} \mathrm{NH}_{4}^{+}$fluxes in rice roots kinetics and compartmental analysis. Plant Physiology, Minneapolis, v. 116, n. 2, p. 581-587, 1998.

LAL, R. Soil carbon sequestration to mitigate climate change. Geoderma, Amsterdam, v. 123, n. 1-2, p. 1-22, 2004.

MALAVOLTA, E. Elementos de nutrição mineral de plantas. São Paulo: Agronômica Ceres, 1980. 251 p.

MARSCHNER, H. Mineral nutrition of higher plants. $2^{\text {nd }}$ ed. London: Academic Press, 1995. 889 p.

MARTINS, D.; MARTINS, C. C.; COSTA, N. V. Allelopathic potential of solutions of soils cultivated with Brachiaria brizantha: effects on some pasture grass and weeds seeds. Planta Daninha, Viçosa, v. 24, n. 1, p. 6170, 2006.

NASCENTE, A. S.; CRUSCIOL, C. A. C. Cover crops and herbicide timing management on soybean yield under no-tillage system. Pesquisa Agropecuária Brasileira, Brasília, v. 47, n. 2, p. 187-192, 2012.

NASCENTE, A. S.; CRUSCIOL, C. A. C.; COBUCCI, T. The no-tillage system and cover crops - alternatives to increase upland rice yields. European Journal of Agronomy, Amsterdã, v. 45, p. 124-131, 2013 a.

NASCENTE, A. S.; CRUSCIOL, C. A. C.; STONE, L. F.; COBUCCI, T. Upland rice yield as affected by previous summer crop rotation (soybean or upland rice) and glyphosate management on cover crops. Planta Daninha, Viçosa, v. 31, n. 1, p. 147-155, 2013b.

NASCENTE, A. S.; KLUTHKOUSKI, J.; RABELO, R. R.; OLIVEIRA, P.; COBUCCI, T.; CRUSCIOL, C. A. C. Upland rice yield under different soil management systems and nitrogen application times. Pesquisa Agropecuária Tropical, Goiânia, v. 41, n. 1, p. 60-65, 2011.

NASCENTE, A. S.; PEREIRA, W.; MEDEIROS, M. A. Weed interference in processing tomato crops. Horticultura Brasileira, Brasília, v. 22, n. 3, p. 602-606, 2004.

NORTON, J. M. Nitrification. In: SUMMER, M. E. (Ed.). Handbook of soil science. Boca Raton: CRC Press, 2000. p. C160-C181.
OLIVEIRA, P. de. Consórcio de milho com adubos verdes e manejo da adubação nitrogenada no cultivo de feijão em sucessão no sistema integração lavoura-pecuária no Cerrado. 2010. Tese (Doutorado em Fitotecnia) - Escola Superior de Agricultura Luiz de Queiroz. Universidade de São Paulo, Piracicaba.

OONYU, J. Upland rice growing: a potential solution to declining crop yields and the degradation of the Doho wetlands, Butaleja district-Uganda. African Journal of Agricultural Research, Nairobi, v. 6, n. 12, p. 2774-2783, 2011.

OWEN, A. G.; JONES, D. L. Competition for amino acids between wheat roots and rhizosphere microorganisms and the role of amino acids in plant $\mathrm{N}$ acquisition. Soil Biology and Biochemistry, Elmsford, v. 33, n. 4-5, p. 651-657, 2001.

PACHECO, L. P. Arroz de terras altas cultivado em sucessão a plantas de cobertura em sistemas de manejo do solo. 2009. Tese (Doutorado em Agronomia) - Escola de Agronomia e Engenharia de Alimentos. Universidade Federal de Goiás, Goiânia.

POLETTO, N.; GROHS, D. S.; MUNDSTOCK, C. M. Ammonium and nitrate seasonal and daily fluctuation in a typical red dysthropic argisol. Revista Brasileira de Ciência do Solo, Viçosa, v. 32, n. 4, 1619-1626, 2008.

QU, Y.; PING, M.; HONGLIANG, Z.; CHEN, Y.; GAO, Y.; TIAN, Y.; WEN, F.; LI, Z. Mapping QTLs of root morphological traits at different growth stages in rice. Genetica, Dordrecht, v. 133, n. 2, p. 187-200, 2008.

ROSOLEM, C. A.; WERLE, R.; GARCIA, R. A. Nitrogen washing from $\mathrm{C} 3$ and $\mathrm{C} 4$ cover grasses residues by rain. Revista Brasileira de Ciência do Solo, Viçosa, v. 34, n. 6, p. 1899-1905, 2010.

SAITO, K.; LINQUIST, B.; ATLIN, G. N.; PHANTHABOON, K.; SHIRAIWA, T.; HORIE, T. Response of traditional and improved upland rice cultivars to $\mathrm{N}$ and $\mathrm{P}$ fertilizer in northern Laos. Field Crops Research, Amsterdam, v. 96, n. 2-3, p. 216-223, 2005.

SAS INSTITUTE. Procedure guide for personal computers. Version 5. Cary, 1999.

SCHJOERRING, J. K.; HUSTED, S.; MACK, G.; MATTSSON, $M$. The regulation of ammonium translocation in plants. Journal of Experimental Botany, Oxford, v. 53, n. 370, p. 883-890, 2002.

SOUZA FILHO, A. P. S.; RODRIGUES, L. R. A.; RODRIGUES, T. J. D. Allelopathic potential of tropical forages: effects on pasture weeds. Planta Daninha, Viçosa, v. 15, n. 1, p. 53-60, 1997. 
SOUZA, L. S.; VELINI, E. D.; MARTINS, D.; ROSOLEM, C. A. Allelopathic effects of Brachiaria decumbens on the initial development of seven crops. Planta Daninha, Viçosa, v. 24, n. 4, p. 657-668, 2006.

TAO, H. B.; BRUECK, H.; DITTERT, K.; KREYE, C.; LIN, S.; SATTELMACHER, B. Growth and yield formation of rice (Oryza sativa L.) in the water-saving ground cover rice production system (GCRPS). Field Crops Research, Amsterdam, v. 95, n. 1, p. 1-12, 2006.

THOMAS, R. J.; ASAKAWA, N. M. Decomposition of leaf litter from tropical forage grasses and legumes. Soil Biology and Biochemistry, Elmsford, v. 25, n. 10, p. 1351-1361, 1993.
VEIGA, M.; REINERT, D. J.; REICHERT, J. M. Tillage systems and nutrient sources affecting soil cover, temperature and moisture in a clayey oxisol under corn. Revista Brasileira de Ciência do Solo, Viçosa, v. 34, n. 6, p. 2011-2020, 2010.

WANG, M. Y.; SIDDIQI, M. Y.; RUTH, T. J.; GLASS, A. D. M. Ammonium uptake by rice roots: 1 . fluxes and subcellular distribution of ${ }^{13} \mathrm{NH}_{4}^{+}$. Plant Physiology, Minneapolis, v. 103, n. 4, p. 1249-1258, 1993.

YAHUZA, I. Review of some methods of calculating intercrop efficiencies with particular reference to the estimates of intercrop benefits in wheat/faba bean system. International Journal of Bioscience, Dhaka, v. 1, n. 1, 1830, 2011. 